\title{
Assessment of the relationship between the engagement in leisure time and academic motivation among the students of faculty of education
}

\author{
Ihsan SARI ${ }^{1}$, Mehmet Cagri CETIN ${ }^{2}$, Erdi KAYA ${ }^{3}$, Mahmut GULLE ${ }^{2}$, \\ Recep KAHRAMANOĞLU²
}

${ }^{1}$ Department of Physical Education and Sport, Sakarya University, Turkey.

${ }^{2}$ Department of Physical Education and Sport, Mustafa Kemal University, Turkey.

${ }^{3}$ Department of Physical Education and Sport, Ibrahim Cecen University, Turkey.

Address correspondence to M. Cagri Cetin, mccetin80@gmail.com.

\begin{abstract}
The aim of the study was to determine the relationship between leisure time motivation and academic motivation among the students who studied at the Faculty of Education of Mustafa Kemal University. 260 students (Xyears: 21.29 2.11) constituted the sample of the study. For the analyses of the data; Leisure Motivation Scale and Academic Motivation Scale were employed. The data were analyzed using descriptive statistics, Pearson's correlation test and regression analysis. According to the findings of the study; it was explored that academic motivation was significantly correlated with the leisure motivation scale's subscales of intrinsic motivation toward knowledge and accomplishment $(\mathrm{r}=0.360)$, experience stimulation $(\mathrm{r}=0.219)$ and introjected and identified regulations $(\mathrm{r}=0.212 ; \mathrm{p}<0.05)$. Also; the leisure motivation scale's subscales of motivation toward knowledge and accomplishment accounted for $13 \%$ of academic motivation. In light of these findings; it may be concluded that there was a correlation between academic motivation and intrinsic motivation (toward knowledge and accomplishment, and experience stimulation) and more autonomous types of extrinsic motivation (introjected and identified regulations). As a result of the regression analysis; engagement in leisure time activities for knowledge and accomplishment significantly accounted for academic motivation. In sum; it may be interpreted that participation in leisure time activities with more intrinsic reasons may yield more positive results.
\end{abstract}

Keywords: Leisure time motivation, academic motivation, intrinsic motivation.

\section{INTRODUCTION}

Motivation is explained as the power that leads people to think, act and develop (8). Motivation is the process to obtain and to use available sources like ability, time and energy effectually (19). Although academic motivation is defined as the production of the energy necessary for academic works and deeds; opinions on the source of that energy varies from theory to theory (2).

Motivation concept is also defined as the estimation of presumed intrinsic and/or external powers as the cause of mastery, direction, intense and continuity of behavior (30). Besides; Haggerand Chatzisarantis (12) defined motivation as a directing, guiding and strengthening behavior process. It may be said that motivation plays a key role in individuals' productive learning experiences. The relevant studies indicate that motivation exerts an important and powerful influence upon academic outputs $(16,34,31)$. It is known that learning style and thinking style are important in academic success. However; the fact that academic motivation is very important in terms of individual differences has not been much focused on. Yet; academic motivation deserves a closer attention as it is the most important determinant of academic performance (17) and interestingly; it is necessary that the effect of motivation and selfconcept/personality perceptions upon academic success should be investigated not separately and independently but concurrently and with a causal relationship (11). When the studies on sports field were investigated; it was noted that they focused on individuals' motivation and performance levels $(3,10,13,22,23)$. However; it may be said that the number of the studies that examined the correlation between leisure time and academic motivation is rather small. 
Leisure time -which was used as an educational tool in the United States so that problems of the youth could be solved and the youth could adapt into social life and gain democratic moral valueswas established by National Education Association Educational Policies Commission as the most important subject of education in 1918 (7). Engagement in leisure time activities embraces those activities and doings chosen and joined voluntarily by the individuals themselves in order to rest, to enjoy, to develop the relation with the society and to improve their non-professional trainings after the time for business, work and domestic chores is spent away (21).Participation in leisure time provides the individual with opportunities to divert himself from monotonous and routinized programs forcibly imposed by social institutions and to go beyond himself and to use his creativity (9).

Leisure time is measured with confidencefeeling psychologically provided, respect, creativity and the contribution made to the improvement of the personality through leisure time activities. The type of the leisure time activity chosen for the mental and bodily improvement and acquisition of the knowledge play a role in this measurement. To use leisure time and to rest do not mean not working but changing the type of working (15).

Noticing failure is one of the basic factors affecting motivation. Feeling of unsuccess causes personal perception spiral and personal perception ability to decrease; particularly among the students during the first years of the educational life. Giving tasks that can be achieved by the students whose motivation has reduced may improve their selfconfidence and competition feelings (18). There are studies that scrutinized use of leisure time and participation in sportive activities in relation with academic motivation $(5,6,28)$. Singh et al. (29) investigated most of the important studies in this field and according to the results obtained from these long-term followed up studies where nearly 12.000 children aged between 6 and 18 were examined; they discovered that physical activities affected school success of the students.

In light of the above mentioned information; the aim of the study was to investigate academic motivation levels in relation with leisure time activities among the university students who studied at the Faculty of Education.

\section{MATERIAL AND METHODS}

\section{Model of the Study}

In the study; a method of descriptive survey model and relational screening model was used in order to reveal the current situation (Karasar, 2004).

\section{Study Group}

The study group was composed of the students who studied at the Classroom Teaching Department of Faculty of Education of Mustafa Kemal University during the 2013-2014 academic years. A total of 260 students who were recruited with random sampling method joined the study. 176 of the sample group were female students $(67.7 \%)$ while 84 were male students (33.3\%). Mean age of the participants was $X=21.29$. Participation was voluntary.

\section{Data Collection Tools}

\section{Personal Information Form}

The form included questions about the participants' age, gender, academic grade, educational status of mothers and fathers and income status.

\section{Leisure Motivation Scale}

Leisure Motivation Scale (LMS); developed by Pelletier et al. (27) in order to determine leisure time motivation, was employed. The original scale is composed of 28 items. The Turkish adaptation of the scale was performed by Mutlu (24). According to the factor analyses; six items were excluded from the Turkish version because factor loads of these six items which were written in the original scale were lower than 0.40 . Turkish version of the scale included a total 22 items and five subscales. These subscales were amotivation, intrinsic motivation toward knowledge and accomplishment, experience stimulation, introjected/identified regulations (0.65) and external regulations (0.70).

Total internal consistency coefficient of the scale was 0.77 . In our study; internal consistency coefficients of the subscales ranged between .59 and .74 .

\section{Academic Motivation Scale}

Academic Motivation Scale, developed by Bozanoğlu 2004 (2) in order to measure academic motivation, was used. The scale included 20 items and the scale items had a 5-point Likert format ( $1=$ not suitable at all, $5=$ perfectly suitable). As the result of the factor analyses; it was seen that the scale was clustered into three factors: "going beyond 
oneself", "use of knowledge" and "exploration". Yet, it was explained that scoring can be done by being based on one factor. The lowest score is 20 while the highest score is 100. Higher scores indicate higher academic motivation.

Total internal consistency coefficient of the scale was 0.74 . In our study; it was found out that internal consistency coefficients of the subscales ranged between .62 and .73 .

\section{Analyses of the Data}

The data obtained were computerized. The data were processed in accordance with study aim and were analyzed. For the data analyses; SPSS 15 Statistical Packages for the Social Sciences software was used. The data were analyzed using descriptive statistics, Pearson's correlation test and regression analysis. Level of significance was set at 0.05 .

\section{RESULTS}

According to descriptive statistics results related with academic motivation and leisure time motivation; when max. and min. scores were examined, it was found out that mean score was 69.51 for academic motivation, 2.26 for amotivation, 3.44 for intrinsic motivation toward knowledge and accomplishment, 3.39 for experience stimulation,
3.40 for introjected/identified regulations and 2.53 for external regulations.

As seen Table 2, it was noted that academic motivation demonstrated a significant correlation with the leisure motivation scale's subscales of intrinsic motivation toward knowledge and accomplishment $(\mathrm{r}=0.360)$, experience stimulation $(\mathrm{r}=0.219)$ and introjected and identified regulations $(\mathrm{r}=0.212 ; \mathrm{p}<0.05)$.

When regression analyses results were examined; a significant model was seen $(\mathrm{p}<0.05)$. The subscale of intrinsic motivation toward knowledge and accomplishment accounted for academic motivation score by $13 \%$.

\section{DISCUSSION}

When the leisure time motivation scores of the participant students of educational faculty were investigated; it was seen that the highest score was in intrinsic motivation toward knowledge and accomplishment while the lowest score was in motivation (Table 1). As far as these results were concerned; it may be argued that study group was engaged in leisure time activities due to such reasons as intrinsic motivation toward knowledge and accomplishment. Besides, the fact that scores of amotivation were lower supported this result, too.

Table 1.Descriptive statistics related with academic motivation and leisure time motivation.

\begin{tabular}{|c|c|c|c|c|c|}
\hline & $\mathrm{N}$ & Min. & Max. & Means & Sd \\
\hline Academic motivation & 260 & 26.00 & 114.00 & 69.51 & 11.97 \\
\hline Amotivation & 260 & 1.00 & 5.00 & 2.26 & .82 \\
\hline Intrinsic motivation toward knowledge and accomplishment & 260 & 1.00 & 5.00 & 3.44 & .73 \\
\hline Experience stimulation & 260 & 1.00 & 5.00 & 3.39 & .81 \\
\hline Introjected/identified regulations & 260 & 1.00 & 5.00 & 3.40 & .64 \\
\hline External regulations & 260 & 1.00 & 5.00 & 2.52 & .76 \\
\hline
\end{tabular}

Table 2. Correlation analyses results related with academic motivation and leisure time motivation.

\begin{tabular}{lcccccc}
\hline Table 2. Correlation analyses results related with academic motivation and leisure time motivation. & Amotivation & $\begin{array}{c}\text { Intrinsic motivation } \\
\text { toward knowledge } \\
\text { and accomplishment }\end{array}$ & $\begin{array}{c}\text { Experience } \\
\text { stimulation }\end{array}$ & $\begin{array}{c}\text { Introjected/identified } \\
\text { regulations } \\
\text { regulations }\end{array}$ \\
\hline Academic Motivation & $\mathrm{r}$ & .073 & $.360^{* *}$ & $.219^{* *}$ & .000 & .060 \\
& $\mathrm{p}$ & .244 & .000 & .001 & .286 \\
\hline
\end{tabular}

Table 3. Regression analyses results related with academic motivation and leisure time motivation.

\begin{tabular}{|c|c|c|c|c|}
\hline & $\mathrm{B}$ & Sd & Beta & $\mathrm{p}$ \\
\hline Intrinsic motivation toward knowledge and accomplishment & 5.932 & .956 & .360 & .000 \\
\hline
\end{tabular}

$\mathrm{R}=0.360 \quad \mathrm{R} 2=0.130$, corrected $\mathrm{R} 2=0.126, \mathrm{~F}=38.492$ 
Yerlisu Lapa et al. (20) conducted a study on 300 physical education teachers employed primary schools and high schools located in Kayseri city center and counties and examined leisure time motivation. When the study results were investigated; it was seen that the highest scores obtained by the physical education teachers were in experience stimulation while the lowest scores were in amotivation. Experience stimulation reflects leisure time motivation due to intrinsic reasons like intrinsic motivation toward knowledge and accomplishment and therefore it may be suggested that the results were in line with our results.

Mutlu et al. (25) conducted a study that investigated a total of 515 individuals -254 male participant $(49.3 \%)$ and 261 female participant (50.7\%)- who participated health and fitness programs organized in Kayseri Metropolitan Municipality Sports Facilities in terms of the factors that encouraged them to join physical activity. The findings of Mutluet al. (25) showed similarities with the findings of our study. According to the results obtained in both studies; experience stimulation, intrinsic motivation toward knowledge and accomplishment, introjected/identified regulations were among the first three factors that motivated individuals to participate in leisure time activities. It was found out that the scores of external regulations were lower than these three subscales while participants' scores of amotivation were the lowest one of the five subscales.

When the correlation results demonstrated in Table 2 were examined, it was observed that academic motivation was significantly correlated with intrinsic motivation toward knowledge and accomplishment, experience stimulation, introjected/identified regulations. As a result of the regression analysis done to discover which motivation accounted for academic motivation; it was noted that intrinsic motivation toward knowledge and accomplishment accounted for 13\% of variance of the academic motivation (Table 3). According to the results of Yerlisu Lapa et al. (20); it was found out that intrinsic motivation toward knowledge and accomplishment, experience stimulation, introjected/identified regulations were significantly correlated with life satisfaction. Huang and Carleton (14) investigated the correlation among leisure time motivation, leisure engagement and life satisfaction with 470 Taiwanese students and concluded that there was a significant correlation between leisure time motivation and life satisfaction.
Considering the positive effect of leisure time motivation; it may be concluded that the above mentioned studies were in agreement with ours.

According to the findings of the current study; it was seen that academic motivation and participation in leisure time activities due to intrinsic reasons and relatively autonomous extrinsic motivation (introjected/identified regulations) were positively correlated. Similarly; it was found out that the subscale of intrinsic motivation toward knowledge and accomplishment significantly accounted for the academic motivation. These findings pointed out that intrinsically participation in leisure time activities particularly for knowledge and accomplishment may be correlated with academic motivation.

When the relevant literature was investigated; it was seen that intrinsic motivation was much more successful in losing weight (32). In a study conducted in relation with quitting smoking; it was seen that wishing to quit smoking due to intrinsic reasons affected the ability to quit smoking and not to resume smoking for 30 days since the time of quitting it (33). According to Nix et al.(26); individuals make bigger efforts, spend much energy and get more positive experiences when their behaviors are rooted in intrinsic causes. Similarly; according to Burton et al. (4); behaviors and acts performed with intrinsic reasons result in positive psychological outcomes such as feeling better about the activity, improving objectives, better psychological well-being.

In the study of Vallerand and Bissonnette (31); it was noted that the students who did not quit but continued the course were intrinsically more motivated towards academic activities. According to another study done with athletes; it was observed that intrinsic motivation levels of the athletes were positively correlated with flow experience (1).

When the above mentioned studies and other studies conducted in different fields are examined; it is reported that intrinsic motivation plays a key role in numerous areas such as education, sports and health. Doing an activity for such intrinsic reasons as knowledge, accomplishment, curiosity and experiencing stimulation produces more positive outcomes as compared with doing the same activity for external reasons. In activities done for intrinsic reasons; personal improvement, entertainment, feeling of success, performing willingly and making more efforts are experienced because the acts and 
behaviors are performed due to intrinsic reasons. In the activities performed due to external reasons; individuals may not get much benefit because they may not fully concentrate on the activity and produce optimal effort.

That participation in leisure time activities due to intrinsic reasons are correlated with academic motivation may have been thanks to the above mentioned points of intrinsic motivation. Students who participate in leisure time activities due to intrinsic reasons may be more motivated for academic works by using their leisure time in the best way.

In light of the results obtained; academic motivation was positively correlated with intrinsic motivation toward knowledge and accomplishment, experience stimulation, introjected/identified regulations. In other words; it was seen that as academic motivation increased so did intrinsic motivation toward knowledge and accomplishment, experience stimulation, introjected/identified regulations. As far as these results were concerned; it may be recommended that opportunities that can allow the university students to use leisure time in more effective way should be provided in order to increase their academic motivation.

\section{REFERENCES}

1. Altıntaş A, Kelecek S, Aşçı FH. Elit sporcularda durumsal güdülenme ve optimal performans duygu durumu arasındaki ilişki. Pamukkale Journal of Sport Sciences, 2013; 4(4), 14-21.

2. Bozanoğlu İ. Akademik güdülenme ölçeği: Geliştirmesi, geçerliği, güvenirliği. Ankara Üniversitesi Eğitim Bilimleri Fakültesi Dergisi, 2004; 37(2), 83-98.

3. Bruin AP, Bakker FC, Oudejans RRD. Achievement goal theory and disordered eating: relationships of disordered eating with goal orientations and motivational climate in female gymnasts and dancers. Psychology of Sport \& Exercise, 2009; 10: 72-79.

4. Burton KD, Lydon JE, D'Alessandro DU, Koestner R. The differential effects of intrinsic and identified motivation on well-being and performance: prospective, experimental, and implicit approaches to self-determination theory. Journal of personality and social psychology, 2006; 91(4): 750

5. Chee KH, Pino NW, Smith WL. Gender differences in the academic ethic and academic achievement. College Student Journal, 2005; 39(3).

6. Peiperl MA, Travelyan R. Predictors of performance at business school and beyond. Journal of Management, 1997; 16: 354-367.

7. Corbin DH. Recreation Leadership, 3.Rd Edition, PrenticeHall, Inc. Englwood Cliffs, N.J 1970; Pp.70-11.
8. Deci EL, Ryan RM. Facilitating optimal motivation and psychological well- being across life's domains. Canadian Psychology, 2008; 49(1), 14-23.

9. Dumazedier J. Free-time activitiy and psycho-social adjusment incollege students: a prelimannary analysis. Journal of Leisure Research, 1974.

10. Fossmo T. Age Matters: A Study on Motivation, Flow And Self-Esteem in Competing Athletes. Hovedoppgave For Graden Cand. Psychol. Institutt for Psykologi, Universitetet İ Tromsø, 2006.

11. Green J, Nelson G, Martin AJ, Marsh H. The causal ordering of self-concept and academic motivation and its effect on academic achievement. International Education Journal, 2006; 7, 534-546.

12. Hagger MS, Chatzisarantis NLD. Intirinsic Motivation and Self-Determination In: Exercise and Sport. Human Kinetics, 2007.

13. Hanrahan S, Cerin E. Gender, level of participation and type of sport: differences in achievement goal orientation and attributional style. Journal of Science and Medicine in Sport, 2005; 1-5.

14. Huang CY, Carleton B. The relationships among leisure participation, leisure satisfaction, and life satisfaction of college students in Taiwan. Journal of Exercise Science and Fitness, 2003; 1(2): 129-132.

15. Köknel Ö. Kaygıdan Mutluluğa Kişilik, Altın Kitaplar Yayınevi, Istanbul.1995.

16. Kuyper H, Van Der Werf MPC, Lubbers MJ. Motivation, meta-cognition and self-regulation as predictors of long term educational attainment. Educational Research and Evaluation, 2000; 6(3), 181-201.

17. Linnenbrink EA, Pintrich PR. Motivation as an enabler for academic success. The School Psychology Review, 2002; 31:313-327.

18. Littlejohn A. Motivation. English Teaching Professional, 2001; (4), S: 5-8

19. Martin JJ, Mushett CA. Social support mechanisms among athletes with disabilities. Adapted Physical Activity Quarterly, 1996; 13: 74-83.

20. Yerlisu Lapa T, Ağyar E, Bahadır Z. Yaşam tatmini, serbest zaman motivasyonu, serbest zaman katılımı: beden eğitimi ve spor öğretmenleri üzerine bir inceleme (Kayseri ili örneği). Spormetre Beden Eğitimi ve Spor Bilimleri Dergisi, 2012; (2): 53-59.

21. Merzona R. Dimensions of Thinking, USA: Semline Inc. Meydanlarousse, 1989; 2 (1): 303-311.

22. Murcia JAM, Gimeno EC, Coll DG. Young athletes' motivational profiles. Journal of Sport Science and Medicine, 2007; 6(3): 172-179.

23. Murcia JAM, Gimeno EC, Coll DG. Relationship among goal orientations, motivational climate and flow in adolescent athletes: differences by gender. The Spanish Journal of Psychology, 2008; 11(1): 181-191.

24. Mutlu İ. Egzersiz yapan kişilerin boş zamanlarına yönelik tutumları üzerine bir araştırma kayseri ili örneği. Yüksek Lisans Tezi. Niğde Üniversitesi, Sosyal Bilimler Enstitüsü, 2008. 
25. Mutlu İ, Yılmaz B, Güngörmüş HA, Sevindi T, Gürbüz B. Bireyleri Rekreasyonel Amaçlı Egzersize Motive Eden Faktörlerin Çeşitli Değişkenlere Göre Karşılaştırılması. Selçuk Üniversitesi Beden Eğitimi ve Spor Bilim Dergisi, 2011; 13(1): 54-61.

26. Nix GA, Ryan RM, Manly JB, Deci EL. Revitalization through self-regulation: The effects of autonomous and controlled motivation on happiness and vitality. Journal of Experimental Social Psychology, 1999; 35(3): 266-284.

27. Pelletier LG, Vallerand RJ, Brière NM, Blais MR. Construction et validation de l'Échelle de motivation vis-àvis les Loisirs (EML). Communication présentée au congrès annuel de la SQRP, Ottawa, ON, 28 octobre. Résumé des communications, 1989; p.146.

28. Sheard M. Hardiness commitment, gender, and age differentiate university academic performance. British Journal of Educational Psychology, 2009; 79(1): 189-204.

29. Singh A, Uijtdewilligen L, Twisk JW, van Mechelen W, Chinapaw MJ. Physical activity and performance at school: a systematic review of the literature including a methodological quality assessment. Archives of Pediatrics and Adolescent Medicine, 2012; 166(1): 49-55.

30. Tenenbaum G, Eklund RC. Handbook of Sport Psychology. Third Edition. John Wiley \& Sons, Inc., 2007.

31. Vallerand RJ, Bissonnette R. Intrinsic, extrinsic, and motivational styles as predictors of behavior: A prospective study. Journal of Personality, 1992; 60(4): 599-620.

32. Williams GC, Grow VM, Freedman ZR, Ryan RM, Deci EL. Motivational predictors of weight loss and weight-loss maintenance. Journal of Personality and Social Psychology, 1996; 70(2): 115-126.

33. Williams GG, Gagné M, Ryan RM, Deci EL. Facilitating autonomous motivation for smoking cessation. Health Psychology, 2002; 21(1): 40.

34. Wolters CA. The relation between high school students' motivational regulation and their use of learning strategies, effort, and classroom performance. Learning and Individual Differences, 1999; 11(3): 281-300. 